\title{
Chronic solvent-induced encephalopathy: diagnosis and course
}

Evelien van Valen. Promotores: prof. dr. F.J.H. van Dijk en mw. prof. dr. M.A.G. Sprangers. Co-Promotores: mw. dr. E.M. Wekking en mw. dr. M.S.E. van Hout. Universiteit van Amsterdam, 23 mei 2018.

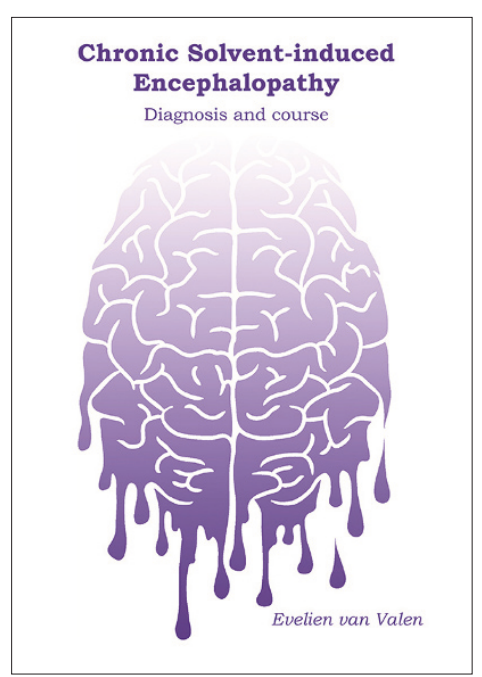

Evelien van Valen, neuropsycholoog en GZ-psycholoog, heeft met haar proefschrift een internationaal standaard werk afgeleverd over chronic solvent-induced encephalopathy (CSE), ook wel chronisch toxische encephalopathie of organisch psychosyndroom (schilderziekte) genoemd. Het is toegankelijk geschreven voor niet in de materie ingevoerde lezers en leest ook nog eens als een spannend verhaal, zo complimenteerde één van de opponenten tijdens de verdediging.

Het proefschrift bevat een historische schets van het proces van herkenning en erkenning van CSE in Finland en Nederland (hoofdstuk 2). De maatschappijbrede belangstelling en bewustwording heeft geleid tot grootschalige preventie. De jaarlijkse incidentie van CSE, vooral onder schilders, blijft afnemen (hoofdstuk 3). Bij een screeningsprogramma onder 40.000 Nederlandse schilders zijn 27 CSE-patiënten gevonden (hoofdstuk 4). De diagnostiek voor CSE is verbeterd door de ontwikkeling van beslisregels, voornamelijk op het gebied van het vaststellen van de ernst van neuropsychologische stoornissen en een verbeterde weging van de waarschijnlijkheid van blootstelling aan oplosmiddelen als oorzaak voor de stoornissen (hoofdstuk 5).

Hoofdstuk 6 beschrijft de ontwikkeling van Europese aanbevelingen voor de neuropsychologische diagnostiek, gebaseerd waar mogelijk op evidentie en anders op consensus van Europese experts. Het neuropsychologische profiel bij CSE-patiënten wordt voornamelijk gekenmerkt door stoornissen op het gebied van aandacht en dan met name de snelheid van informatieverwerking, geheugen en de snelheid van de motoriek. CSE lijkt voornamelijk het geheugenproces van inprenting te beïnvloeden en dit wordt gevonden voor diverse modaliteiten: verbaal, visueel en visuospatiëel geheugen. Het bijeen brengen van internationale experts en ze tot consensus laten komen is geen geringe prestatie. Van Valen is hier met verve in geslaagd. De Europese consensus aanbevelingen verbeteren en harmoniseren de internationale diagnostische criteria voor gebruik in klinische praktijk en wetenschappelijke onderzoek. De wetenschappelijke evidentie wijst in de richting van stabilisatie van de neuropsychologische stoornissen bij CSE na de diagnose, met als waarschijnlijke oorzaak het stoppen of de vermindering van de blootstelling aan organische oplosmiddelen (hoofdstuk 8 en hoofdstuk 9). Voor medici en leken is nog altijd een lastig punt wat de neuropsychologische testen zeggen en wanneer ze geinterpreteerd mogen worden. Van Valen geeft goede uitleg en prestatievaliditeittesten zijn een belangrijk onderdeel van neuropsychologisch onderzoek van CSE (hoofdstuk 6, hoofdstuk 7 en hoofdstuk 10).

De Nederlandse Solvent Teams hebben succesvol samengewerkt op het gebied van klinische diagnostiek, wetenschappelijk onderzoek en het evalueren van het diagnostisch proces voor CSE. Dit heeft de maatschappelijke aandacht voor de schadelijke effecten van beroepsmatige neurotoxische blootstelling verhoogd. In Nederland is de problematiek van CSE bijna opgelost. Echter, oplosmiddelen zijn in andere delen van de wereld nog steeds een probleem. Onze kennis moet toegankelijk zijn voor gebruik in landen waar de werkomstandigheden nog steeds slecht zijn. We moeten streven naar veilige arbeidsomstandigheden voor iedereen en optimale preventie van risicovolle arbeidsomstandigheden die tot een beroepsziekte kunnen leiden. Wie nu denkt dat het Solvent Team overbodig is geworden, heeft het mis. De dagelijkse praktijk wijst uit dat er nog steeds CSE vastgesteld wordt bij werknemers in Nederland en honderden werknemers en verwijzers hebben vragen en zorgen op dit gebied.

\section{Herman Bartstra}

